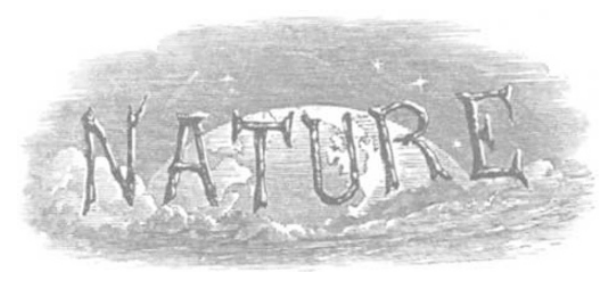

1869-1919.

\title{
JUBILEE ISSUE.
}

THURSDAY, NOVEMBER 6, I9I9.

\section{VALEDICTORY MEMORIES.}

By Sir Norman Lockyer, K.C.B., F.R.S.

$\mathrm{I}^{\mathrm{T}}$ has been suggested to me that some remin1 iscences relating to the circumstances which led to the establishment of NaTure would be of interest, and I am glad to be able to contribute them to this jubilee issue. It is a great satisfaction to me again to have the opportunity of expressing my best thanks to the many friends whose knowledge has always been placed freely at my disposal, and to know that the vitality of the journal is now as strong as ever it was.

At the time when Nature first made its appearance, just fifty years ago, scientific progress was commanding increased attention from the public mind, and British workers were experiencing the need for an organ devoted to their common activities and interests. In 1858 a fortnightly column of scientific notes was started in the Saturday Review, and two years later Huxley became the chief editor of the Natural History Review, with the intention of providing a quarterly which would deal with scientific matters systematically and thoroughly. He ceased to contribute to that magazine, however, in $186_{3}$, and became associated with the Reader, a weekly journal of which I was the science editor.

My first literary work arose from observations of a transit of the shadow of Titan across Saturn's disc. I sent an account of these observations to the London Review, and it appeared in the issue of May Io, 1862. This communication brought me two letters -one from Mr. W. R. Dawes, who was at that time recognised as one of the keenest. astronomical observers in England, and the other from Mr. W. Little asking me to send astroNO. 26ro, VOL. IO4] nomical notes from time to time to the London Review, together with an article each month on the "face of the sky."

$I$ was then living at Wimbledon, and was honorary secretary of the Wimbledon Village Club, on the committee of which were Thomas Hughes, J. M. Ludlow, and George Pollock. It was this connection that led to my appointment as science editor of the Reader, when it was established with Hughes and Ludlow among the proprietors. My astronomical work thus led me into literature, and the subject with which I was particularly concerned-astronomy-was also the product of my Wimbledon environment.

When the Reader ceased publication the idea occurred to me of starting a general scientific journal of a more comprehensive scope than the Natural History Review, which, like other specialised scientific periodicals, had failed for want of circulation. On discussing the matter with my friends, I found that they were favourable to the idea; and one of them, Mr. Alexander Macmillan, greatly encouraged me to develop it. It was in consequence of his sympathy and enthusiastic assistance that the journal was started. He was unwavering in his support of the belief that British science would be advanced by a periodical devoted to its interests-a point on which I had always laid stress as the result of experience up to that time. It was the hope that a more favourable condition for the advancement of science might be thereby secured that led Mr. Alexander Macmillan to enter warmly into the establishment of Nature in 1869 . He enlisted the interest of Sir Joseph Hooker and other of his scientific friends, and before the journal had started I was assured of the support of Huxley, Tyndall, and practically all the other leading workers in science of the time. 
It may be of interest to reprint here the following circular which was issued broadcast to bring the aims and intentions of the journal before scientific readers and others :-

The object which it is proposed to attain by this periodical may be broadly stated as follows. It is intended :

First, to place before the general public the grand results of Scientific Work and Scientific Discovery, and to urge the claims of Science to a more general recognition in Education and in Daily Life; and

Secondly, to aid Scientific men themselves, by givin early information of all advances made in any branch of Natural Knowledge throughout the world, and by affording them an opportunity of discussing the various Scientific questions which arise from time to time.

To accomplish this twofold object, the following plan is followed as closely as possible.

Those portions of the paper more especially devoted to the discussion of matters interesting to the public at large contain :

I. Articles written by men eminent in Science on subjects connected with the various points of contact of Natural Knowledge with practical affairs, the public health, and material progress; and on the advancement of Science, and its educational and civilising functions.

II. Full accounts, illustrated when necessary, of Scientific Discoveries of general interest.

III. Records of all efforts made for the encouragement of Natural Knowledge in our Colleges and Schools, and notices of aids to Science-teaching.

IV. Full Reviews of Scientific Works, especially directed to the exact Scientific ground gone over, and the contributions to knowledge, whether in the shape of new facts, maps, illustrations, tables, and the like, which they may contain.

In those portions of Nature more especially interesting to Scientifio men are given :

$V$. Abstracts of important papers communicated to British, American, and Continental Scientific societies and periodicals.

VI. Reports of the meetings of Scientific bodies at home and abroad.

In addition to the above, there are columns devoted to Correspondence.

From the first I was helped by the free kindness of most of the men of science in the country, by their permitting me to appeal to them for assistance and advice, and my election into the Royal Astronomical Society, and afterwards into the Royal Society, in 1869 , brought me into closer correspondence and contact with many of the active workers in scientific fields. I am very grateful for what they did, and for what men of science are still ready to do to ensure that NATURE shall represent scientific claims justly and scientific fact and thought in correct proportion. While this common interest in the journal exists among men of science, not only in the United Kingdom, but also in Europe and America, there will be no falling off from the high standard maintained in its pages from the commencement of its existence.

$$
\text { No. } 26 \text { IO, VOL. IO4] }
$$

\section{PROGRESS AND PROMISE.}

$\mathrm{N}$ the career of a journal, as in the life of a man, stages are met from which it is appropriate to take a glance backward at the road traversed and to contemplate the outlook of the future. Such an epoch has been reached in the history of NATURE, the first number of which was published fifty years ago-on November 4, I869. The circumstances which led to the establishment of this journal are described briefly by Sir Norman Lockyer in the preceding article. Men of science had felt the need for an organ devoted to their interests in common, and several attempts had been made to meet it, but unsuccessfully. It required the rare combination of scientific authority, untiring energy, wise judgment, and business aptitude to construct a platform on which investigators of the many and diverse fields of natural knowledge could put their trust, and from which descriptions of their work would command attention.

How fully these attributes are possessed by the founder of this journal, and how consistently they have been made manifest in its pages, is shown by numerous appreciative messages received from scientific societies and distinguished workers. Thanks to the sound and comprehensive programme laid down by Sir Norman Lockyer at the beginning, and followed ever since, NATURE now occupies a high place in scientific life. It would be disingenuous to pretend that we are not proud of the testimonies which have been sent by many leading representatives of progressive knowledge as to services rendered by the journal in various ways. Among those who have expressed their congratulations upon the attainment of the jubilee are readers who have never missed a number since the first issue, while others of a new generation equally acknowledge the stimulus they derive from a wide view in these days of minute specialisation.

The intellectual background is different now from what it was in 1869 , and the outlook, as well as the conceptions, of science has changed. Specialised work is necessary to acquire new knowledge, but for the great generalisations which provide an impulse to wide inquiry attention must be given to results achieved in the whole sphere of related investigations. It is the particular function of NATURE to present this comprehensive view, and to bring to a focus upon its pages the living picture of scientific advance as a whole, so that workers in separate fields may see the growth of the grand edifice of natural knowledge, and the place their own contributions take in it. 